\title{
SPANXN2 wt Allele
}

National Cancer Institute

\section{Source}

National Cancer Institute. SPANXN2 wt Allele. NCI Thesaurus. Code C92989.

Human SPANXN2 wild-type allele is located in the vicinity of Xq27.3 and is approximately $9 \mathrm{~kb}$ in leng th. This allele, which encodes sperm protein associated with the nucleus on the $\mathrm{X}$ chromosome $\mathrm{N} 2$ protein, may be involved in male gamete differentiation. 